\title{
РОЗВИТОК СИЛОВИХ ЯКОСТЕЙ ЛЕГКОАТЛЕТІВ-МЕТАЛЬНИКІВ ГРУП ПІДВИЩЕННЯ СПОРТИВНОЇ МАЙСТЕРНОСТІ ЗА ДОПОМОГОЮ ЗАСОБІВ КРОСФІТУ
}

\author{
Оксана Саволайнен ${ }^{1}$, Валерій Кузнецов ${ }^{2}$, Олександр Валькевич ${ }^{3}$, \\ Роман Черкашин ${ }^{3}$, Людмила Черкашина ${ }^{3}$ \\ ${ }^{1}$ Національний університет фізичного виховання і спорту України, Київ, Україна \\ ${ }^{2}$ Київський національний економічний університет імені Вадима Гетьмана, Київ, Україна \\ ${ }^{3}$ Східноєвропейський національний університет імені Лесі Українки, Луцьк, Україна, lcherkashina1983@i.ua
}

https://doi.org/10.29038/2220-7481-2019-02-112-119

\section{Анотації}

Актуальність дослідження зумовлена впровадженням у навчально-тренувальний процес студентів, котрі займаються в групах підвищення спортивної майстерності (група метання), популярного в Україні виду рухової активності - кросфіт, у програму якого входять функціональні комплексні вправи силової спрямованості. Мета дослідження - розробити та експериментально перевірити вплив кросфіт-програми на підвищення рівня силових якостей та спортивної майстерності легкоатлетів-метальників закладів вищої освіти. Результати дослідження. Аналізуючи результати тестування на початку експерименту, ми виявили, що контрольна група майже за всіма показниками перевищує результати учасників експериментальної групи, але водночас потрібно відзначити, що якщо взяти середні показники, то експериментальна група мала показники не гірші за контрольну. Це видно в застрибуваннях на тумбу 50 см за 30 секунд, динамометрії лівої кисті та висі на зігнутих руках, де зафіксовано незначну перевагу. Результати проведених досліджень у кінці експерименту засвідчують, що вищий відсоток приросту показників силової підготовленості спостерігаємо в легкоатлетів-метальників ЕГ, порівняно з КГ, який у середньому становив у вибуховій силі $12,25 \%$, у максимальній силі $-6,75 \%$ та в силовій витривалості (статичній і динамічній) - 20,75 \%. До того ж, якщо на початку експерименту ЕГ поступалась у спортивній майстерності, маючи шість результатів рівня III розряду й два - II-го, порівняно з 5-ма результатами третього розряду КГ та 3-ма результатами II-го, то в кінці експерименту простежуємо динаміку підвищення спортивної майстерності в ЕГ (7II розряд, 1-І-й), порівняно з КГ (6-II розряд, 2-III-й). Висновки. Результати проведеного педагогічного експерименту свідчать, що програма підвищення рівня силових якостей метальників із використанням засобів кросфіту сприяла розвитку сили, швидкості та потужності в метальників і вивела тренувальний процес у метаннях на більш високий, якісний рівень.

Ключові слова: кросфіт, силові якості, силова підготовленість, легкоатлети-метальники, підвищення спортивної майстерності, заклади вищої освіти.

Оксана Саволайнен, Валерий Кузнецов, Александр Валькевич, Роман Черкашин, Людмила Черкашина. Развитие силовых качеств легкоатлетов-метателей групा повышения спортивного мастерства при помощи средств кросфита. Актуальность исследования обусловлена внедрением в учебно-тренировочный процесс студентов, занимающихся в группах повышения спортивного мастерства, популярного в Украине вида двигательной активности кросфита, в программу которого входят функциональные комплексные упражнения силовой направленности. Цель исследования - разработать и экспериментально проверить влияние Кросфит-программы на повышение уровня силовых качеств и спортивного мастерства легкоатлетов-метателей в учреждениях высшего образования. Результаты исследования. Анализируя результаты тестирования в начале эксперимента, мы наблюдаем, что контрольная группа почти по всем показателям превышает результат участников экспериментальной группы, но в тоже время, необходимо отметить, что если взять средние показатели, то экспериментальная группа имеет результаты не хуже чем контрольная. Это видно в заскакивании на тумбу 50 см за 30 секунд, динамометрии левой кисти и висе на согнутых руках, где фиксируется незначительное преимущество. Результаты проведенных исследований в конце эксперимента свидетельствуют, что выше процент прироста показателей силовой подготовленности отмечается у легкоатлетов-метателей ЭГ, по сравнению с КГ, который в среднем составил во взрывной силе $12,25 \%$, в максимальной $-6,75 \%$ и в силовой выносливости (статической и динамической) - 20,75 \%. Кромк того, если в начале эксперимента ЭГ уступала в спортивном мастерстве, имея шесть результатов уровня III разряда и два - II-го, по сравнению с 5-ю результатам третьего разряда КГ и 3-мя - II-го, то в конце эксперимента наблюдается динамика повышения спортивного мастерства в ЭГ (7-II разряд, 1-І-й), по сравнению с КГ (6-II разряд, 2-III-й). Выводы. Результаты проведенного педагогического эксперимента свидетельствуют, что программа повышения уровня силовых качеств метателей с использованием средств кросфита 
способствовала развитию силы, скорости и мощности в метателей и вывела тренировочный процесс в метаниях на более высокий, качественный уровень.

Ключевые слова: кросфит, силовые качества, силовая подготовленность, легкоатлеты-метатели, повышение спортивного мастерства, учреждения высшего образования.

Oksana Savolaynen, Valeriy Kuznetsov, Oleksandr Valkevych, Roman Cherkashyn, Lyudmyla Cherkashyna. Development of Power Qualities of Athlete-Throwers' Groups of Increased Sportsmastery Using Crossfit Techniques. Topicality of the study is caused by the introduction into the training process of students engaged in enhancement sports skills groups (the group of throw), a popular type of motor activity in Ukraine, a crossfit. The program of which includes functional complex exercises of power direction. The purpose of the study is to develop and experimentally test the impact of the Crosfit program on raising the level of strength and athletic skills of the track and field athletes-throwers of higher education institutions. Results of the Research. Analyzing the results of the test at the beginning of the experiment, we have found that the control group (CG) exceeds the results of the experimental group (EG) in almost all of the indicators, but at the same time it should be noted that if we take average indicators, thus the experimental group showed results not worse than the control group. This is evident in jumping on a $50 \mathrm{~cm}$ pedestal for 30 seconds, also the left hand dynamometry and the flexed arm hangs, where a slight advantage was recorded. The results of the conducted researches at the end of the experiment indicate that higher percent of the increase in strength training indicators is noted at the track and field athletes-throwers of EG compared with the CG, which at the explosive force averagely was 12,25\%, accordingly at maximum strength $-6,75 \%$ and in force endurance (static and dynamic) $-20,75 \%$. In addition, if at the beginning of the experiment, EG was inferior at the athletic skills with 6 results of the $3^{\text {rd }}$ grade level and 2 of the $2^{\text {nd }}$ grade compared to 5 results of the $3^{\text {rd }}$ grade of CG and 3 results of the $2^{\text {nd }}$ grade. Then at the end of the experiment there is a dynamics of increasing athletic skill at EG ( $7-$ the $2^{\text {rd }}$ grade, $1-1^{\text {st }}$ grade $)$ in comparison with CG $\left(6-2^{\text {nd }}\right.$ grade, $2-3^{\text {rd }}$ grade $)$. Conclusions. The results of the conducted pedagogical experiment indicate that the program for increasing the level of power qualities of the throw athletes using the means of Crosphit contributed to the development of strength, speed and power of the throw athletes and had led the throwing training process to a high-quality level.

Key words: Crossfit, power quality, strength training, track and field athletes-throwers, sporting skills enhancement, higher education institutions.

Вступ. У зв'язку зі значним зростанням спортивних досягнень у легкоатлетичних метаннях, високою конкуренцією, розширенням календаря змагань, зміною умов змагань (динамічна легка атлетика) постала потреба в удосконаленні тренувального процесу в групах підвищення спортивної майстерності вищих закладів освіти. Наявний арсенал загальноприйнятих тренувальних програм, який пропонується в тренувальному процесі в групах підвищення спортивної майстерності (легкоатлетичні метання), повною мірою не може виконати це завдання.

Відтак потрібний пошук нових засобів та методів тренування, які б сприяли покращенню рівня силових якостей і конкурентоспроможності на всеукраїнських та міжнародних змаганнях легкоатлетівметальників.

Важливим кроком у розвитку рухових якостей, зокрема сили, на тренувальних заняттях може стати запровадження такого, що набирає популярності в Україні, виду рухової діяльності, як CrossFit. Цей термін походить від англійських слів «cross», що в перекладі означає «перетинати, перехресний», i «fitness»«пристосованість, здатність до витривалості».

Програму «Кросфіт» розроблено Грегом Гласманом для підвищення компетентності людей під час виконання будь-яких фізичних задач. Для програми, що отримала назву «Кросфіт», поставлено конкретне завдання - зробити людей більш сильними та витривалими. Ідея кросфіту полягає в об'єднанні силового й кардіотренування. Поєднання силового та аеробного тренінгу сприяє розвитку силових якостей, підвищенню працездатності, зміцненню здоров'я. При цьому, зазвичай, у програмі тренування кросфіту поєднуються вправи з гімнастики, легкої атлетики, гирьового спорту, пауерліфтингу та інших видів спорту.

На думку науковців, які займалися дослідженням ефективності програм кросфіту в різних галузях спортивної діяльності, кросфіт - це вид фітнесу, у програму якого входять функціональні комплексні вправи силової спрямованості, що виконуються в аеробному режимі в зоні високої інтенсивності $[1 ; 2 ; 4$.$] .$ Також науковці зазначають, що кроссфіт - це екстремальна система загальної фізичної підготовки, заснована на базових рухах із різних видів спорту, котрі постійно чергуються [3; 5]

Інакше кажучи, кросфіт можна описати як програму силових вправ, що складається 3 «постійно змінних функціональних вправ високої інтенсивності», кінцевою метою яких є покращення загальної фізичної форми, реакції й готовності до будь-якої життєвої ситуації, що вимагає активних фізичних дій [7; 8].

Під час аналізу науково-методичної літератури нами не виявлено жодної розробки стосовно теми використання засобів кросфіту в тренувальному процесі метальників у групах підвищення спортивної 
майстерності. Існує лише невелика кількість науково-дослідницьких праць із цього напряму, які мають тільки описовий характер $[6 ; 10 ; 11]$.

Отже, ми вважаємо, що такий популярний нині в Україні вид рухової діяльності, як кросфіт, адаптований під тренувальний процес у легкоатлетичних метаннях у групах підвищення спортивної майстерності, є тим інноваційним підходом, що сприятиме розвитку сили, швидкості й потужності в легкоатлетівметальників і виведе тренувальний процес на більш якісний рівень.

Мета дослідження - розробити та експериментально перевірити вплив кросфіт-програми на підвищення рівня силових якостей і спортивної майстерності легкоатлетів-метальників закладів вищої освіти.

Матеріал і методи дослідження включали теоретичний аналіз й узагальнення науково-методичної літератури, бесіди з фахівцями, педагогічне спостереження, педагогічний експеримент, методи математичної статистики.

Навчально-тренувальні заняття в контрольній групі проводили відповідно до загальноприйнятої програми «Підвищення спортивної майстерності» 3 легкої атлетики. Навчально-тренувальні заняття в експериментальній групі включали тренувальні заняття, побудовані на принципах системи «Кросфіт».

Відповідно до мети дослідження сформовано експериментальну $(\mathrm{E} \Gamma, \mathrm{n}=12)$ та контрольну групи (КГ, n=12), до яких увійшли студенти 1-2 курсів, котрі займалися в групі підвищення спортивної майстерності з легкої атлетики (група метань) і на момент початку експерименту мали II- та III-й спортивні розряди. На момент дослідження метальники, котрі брали участь в експерименті, не скаржилися на стан здоров'я й самопочуття. Від усіх учасників отримано письмову згоду на участь у нашому дослідженні, що проводилося на базі Київського національного економічного університету імені Вадима Гетьмана та Східноєвропейського національного університету імені Лесі Українки.

Кросфіт-програму впроваджено в осінньо-зимовий підготовчий період 2018-2019 р. Уключення кросфіт-тренувань відбувалося під час навчально-тренувальних занять із підвищення спортивної майстерності з легкої атлетики (група метання) чотири рази на тиждень. Загальна кількість сягала 48 тренувальних занять, а час, що відводився на кожне кросфіт-тренування, становив 25-35 хв. Провідними методами за використання комплексів вправ 3 арсеналу кросфіту були метод колового тренування, інтервальний і повторний методи.

Для визначення ефективності запропонованої програми на початку та в кінці експерименту використано такі тестові вправи, як стрибок у довжину з місця, потрійний стрибок 3 місця, кидок ядра 5 кг через голову назад, стрибки на тумбу 60 см за 30 сек, кистьова динамометрія, жим штанги лежачи, присідання зі штангою, вис на зігнутих руках, утримання ніг у положенні лежачи, підйом у сід за 30 сек, присідання за 20 сек.

Результати дослідження. Американський гімнаст Г. Глассман писав, що рецептом кросфіту $є$ «постійно варійовані високоінтенсивні функціональні рухи». Науковець пояснював, що функціональні рухи використовують універсальні шаблони рекрутування, які виконуються за допомогою скорочення від ядра до кінцівок і $є$ складними, тобто багатосуглобовими. Найважливіший фактор функціональних рухів - їх здатність переміщати великі обтяження на довгі дистанції й робити це швидко. А сукупно три атрибути (вага, дистанція та швидкість) визначають спроможність функціональних рухів виробляти високу потужність.

А. Г. Галімова, М. Д. Кудрявцев, В. А. Глибокий, Г. Я. Галімов науково обгрунтували зміст високоінтенсивного багатофункціонального тренінгу кросфіту й висловили припущення, що, незалежно від трудової спеціалізації, найбільш значущі групи м'язів, що визначають нормальну життєдіяльність людини, повинні мати гарний розвиток [4].

За даними С. А. Єрьоміна та В. В. Волкова, рівень фізичного розвитку спортсменів, які займаються кросфітом, вирізняється високими показниками м'язової маси, силовими можливостями м'язів рук i тулуба, споживанням кисню на рівні анаеробного порога та максимальної алактатної потужності, збільшеною мінеральною щільністю кісткової тканини й ударним об’ємом серця [3].

Базилевич Н. О., Тонконог О. С., Д. А. Кокорєв у своїх працях розкривали особливості застосування кроссфіту у фізичному вихованні студентів та вивчали його вплив на формування мотивації студентів до регулярних занять фізичною культурою й спортом [2].

Під час опрацювання науково-методичної літератури з проблеми дослідження, бесід із фахівцями та спостереження за тренувальними заняттями груп підвищення спортивної майстерності нами розроблено кросфіт-програму, спрямовану на підвищення рівня силових якостей легкоатлетів-метальників. Крім того, передбачено, що, підвищивши рівень силових якостей, метальники піднімуть свою спортивну майстерність, що дасть можливість виконати спортивні розряди, передбачені єдиною спортивною класифікацією України. 
Під час побудови навчально-тренувальних занять ми використовували такі положення, як: а) використання кросфіт-тренувань відбувалось у всіх частинах тренування із застосуванням різних засобів $\mathrm{i}$ методів; б) переважне використання засобів силової та швидкісно-силової підготовки, що є необхідним для подальшого збільшення вибухової сили в процесі виконання змагальних вправ; в) для більшої ефективності розвитку силових якостей і підвищення арсеналу володіння руховими навичками під час кожного тренування використовували велику кількість різноманітних вправ; г) вправи чергували залежно від роботи певних м'язових груп;

Комплекси вправ за системою кросфіту, що використовувався в дослідженні

Понеділок. Комплекс вправ за системою кросфіту складався 3 двох блоків та виконувався в вкінці підготовчої - на початку основної частини заняття.

Перший блок. Завдання - виконати п’ять раундів за 25 хв. Вправи виконувалися послідовно одна за одною. Їх дозування відбувається за схемою «30 сек - навантаження, 30 сек - відпочинок». Усі вправи виконуються з максимальною інтенсивністю й максимальною кількістю повторів за 30 сек. Вправи: 1. Присід зі штангою 40 кг. 2. Берпі з підтягуванням. 3. Піднімання в сід із поштовхом (кидком) набивного м'яча в стіну. 4. Жим штанги 40 кг.

Другий блок. Вправи виконували послідовно одна за одною без зупинки. Завдання - виконати задані вправи 3 певною кількістю повторень, а саме - 18-15-12-9-6-3. Дозування - 1 раунд. Загальний час, затрачений на комплекс, -15 хв. ЧСС під час виконання головного комплексу - 158-170 уд/хв. Вправи: 1. Кидок набивного м'яча 4 кг із підсіду вгору в стіну на висоту 3 м. 2. Застрибування на підвищення 50 см. 3. Підйом у сід із кидком набивного м’яча в стіну. 4. «Берпі».

Після комплексу виконували відновлювальний біг із ЧСС 130-120 уд/хв, вправи на відновлення та розтягнення, після чого спортсмени приступали до відпрацювання технічних дій із виду метання 3 предметами (снаряди для метання) і без них.

Виконання метальних вправ із легкоатлетичними снарядами відбувалось у такій послідовності: 1) метання тяжкого/змагального/облегшеного снаряда - 3 серії; 2) метання облегшеного/змагального/ тяжкого снаряда -3 серії; 3) метання змагального/тяжкого/легкого снаряда -3 серії. Снаряди метають один за одним у зазначеній послідовності без відпочинку. Після кожної серії спортсмен робить прискорення до місця приземлення снарядів, назад повертається кроком. По завершенню кожних 3-х серій відпочинок 8 хв, під час якого виконуються імітаційні вправи.

Середа. Комплекс вправ за системою кросфіт складався 3 двох блоків і виконувався в головній частині тренувального заняття. Між блоками - відпочинок 10 хв, під час якого виконували імітаційні вправи 3 предметами та без. Час, витрачений на перший блок, -10 хв, на другий -20 хв. ЧСС під час виконання основних комплексів - 170-182 уд/хв.

Перший блок. Завдання - виконати комплекс вправ за мінімальний проміжок часу. Вправи робили послідовно одна за одною без відпочинку в раунді. Дозування - 1 раунд. Кількість повторів у вправі $-8-$ 20. Вага обтяження - від 24 кг до 60 кг. Вправи: 1. Підйом штанги 40 кг на груди та поштовх («трастер») вісім разів. 2. «Берпі» - 10 разів. 3. Станова тяга 60 кг - вісім разів. 4. Махи гирею 24 кг - 10 разів. 5. Пійом у сід - 15 разів. 6. Поштовх штанги 40 кг - вісім разів. 7. Випади зі штангою 30 кг над головою по вісім на кожну ногу. 8. Стрибки на скакалці - 20 разів.

Другий блок. Завдання - виконати три раунди за 20 хв. Вправи робимо послідовно одна за одною 3 відпочинком після бігу 10 сек та відпочинком між раундами 60 сек. Дозування у вправах - вісім повторень. Вправи: 1. Перекид (кантовка) покришки+ стрибок через покришку з обертом. 2. Біг 60 м. 3. Упор лежачи-упор лежачи зігнувши руки (віджимання). 4. Біг 60 м. 5. Кидки набивного м'яча 4 кг у стіну на висоту 4 м. 6. Біг 60 м. 7. Піднімання ніг догори з вису. 8. Біг 60 м. Після комплексу вправ за системою кросфіту в завершаьній частині заняття виконуємо відновлювальний біг із ЧСС 130-120 уд/хв, вправи на розтягнення.

П'ятниця. На початку тренувального заняття спортсмени відпрацьовують технічні дії з виду метання з предметами та без них. Виконання метальних вправ із легкоатлетичними снарядами відбувалось у такій послідовності: 1. Метання змагального/тяжкого/легкого снаряда - три серії. 2. Метання облегшеного/змагального/тяжкого снаряда - три серії. 3. Метання тяжкого/змагального/облегшеного снаряда три серії. Снаряди метаємо один за одним у зазначеній послідовності без відпочинку. Після кожної серії спортсмен робить прискорення до місця приземлення снарядів, назад повертається кроком. Після завершення кожних 3-х серій - відпочинок 8 хв, під час якого виконуються імітаційні вправи.

Комплекс вправ за системою кросфіту складався з двох блоків і виконувався в кінці основної частини заняття. Орієнтовний час, витрачений на перший блок, -20 хв, на другий - 10 хв. ЧСС під час виконання основних комплексів - 170-182 уд/хв. 
Перший блок: завдання - виконати дев'ять раундів комплексу із такою кількістю повторень для кожної вправи в раунді: 3-5-7-9-11-9-7-5-3. Один раунд - вистрибування на тумбу, пробігання відрізка в 15 м із максимальною швидкістю, берпі. Це означає, що в першому раунді треба зробити три вистрибування на тумбу, пробігти три відрізки по 15 м та виконати три берпі. У другому раунді - те саме, але по п'ять разів і т. ін. Відпочинок робити за необхідності.

Другий блок. Вправи виконувались із поступовим збільшенням навантаження та кількості повторень вправи зі штангою й сталим дозуванням навантаження в стрибках. Вправи робили 3 відпочинком між ними 30 сек. Вправи: 1. Станова тяга 30 кг (14 разів) + стрибок на підвищення 50 см (12 разів). 2. Станова тяга 40 кг (12 разів) + стрибок на підвищення 50 см (12 разів). 3. Станова тяга 50 кг (10 разів) + стрибок на підвищення 50 см (12 разів). 4. Станова тяга 60 кг (8 разів) + стрибок на «тумбу» 50 см (12 разів). Після виконання вправ у завершальній частині заняття - відновлювальний біг та вправи на розтягнення.

Субота. Комплекс вправ за системою кросфіту для самостійного опрацювання (активний відпочинок). Вправи виконували послідовно одна за одною по 20 секунд кожна без відпочинку в раунді. Перерва в між раундами - 120 секунд. Дозування - три раунди. Загальний час, затрачений на комплекс, -20 хв. ЧСС під час виконання підвідних вправ - 135-147 уд/хв. Вправи: 1. Перехід з упору лежачи на ліктях («планка») в упор на прямі руки й відведення зігнутої ноги вбік. 2. «Берпі» (упор присівши-упор лежачиупор присівши-вистрибування) на одній нозі - по 15 сек на кожну ногу. 3. Почергові випади в стрибку. 4. Із положення «упор лежачи» зближення й віддалення точок опори. 5. Присід-підйом («повітряний присід»). Після підйому доторкнутися коліном різнойменного ліктя. 6. «Повітряний присід» із махом лівої (правої) ноги в сторону. 7. Біг в упорі («скелелаз»). 8. Стрибки - ноги нарізно, руки вгору-ноги разом, руки вниз. Після комплексу виконуються імітаційні вправи 3 техніки метання з предметами та без - 10 хв.

Загальні вказівки до виконання комплексів: 1. Відпочивати між вправами та раундами не бажано. Вiпочинок робити лише за необхідності. Зупинитися можна на декілька секунд, якщо спортсмен відчуває надмірну втому. 2. Перехід до наступної вправи робити лише після закінчення виконання вказаної кількості разів у попередній вправі. 3. Вправи виконуються в тій послідовності, яка вказана в завданні, переставляти їх місцями або розбивати на меншу кількість повторень не можна. 4. Відпочинок між блоками - до повного відновлення дихання.

Загальні рекомендащії за використання тренувальної програми: залежно від рівня підготовленості спортсмена кількість вправ у серії і кількість серій можуть зменшуватися. Відпочинок між раундами потрібно регулювати за пульсом. Кожний наступний раунд треба починати після повернення частоти пульсу до 100-110 уд/хв. Якщо частота пульсу після раунду більш ніж 5-6 хв залишається на рівні вище 120 уд/хв, то це свідчить про занадто велике навантаження або поганий стан здоров'я спортсмена. Потрібно зменшувати кількість вправ у серії або кількість серій до тих пір, поки пульс не знизиться до 100-120 уд/хв.

Дискусія. Аналізуючи результати тестування на початку експерименту, ми виявили, що контрольна група майже за всіма показниками перевищує результат учасників експериментальної групи, але водночас потрібно відзначити, що якщо взяти середні показники, то експериментальна група мала результати не гірші ніж контрольна (табл. 1). Це видно в застрибуваннях на тумбу 50 см за 30 сек, динамометрії лівої кисті та висі на зігнутих руках, де зафіксовано незначну перевагу.

Аналіз результатів у кінці експерименту дав підставу констатувати, що силові якості покращилися в обох групах, але в експериментальній ці показники набагато вищі завдяки запропонованій у підготовчому періоді програмі підвищення силових якостей засобами кросфіту.

Покращення показників вибухової сили в кінці експерименту в стрибку в довжину в ЕГ становило 21,03 см, або $11 \%(\mathrm{t}-3,24, \mathrm{p}<0,05)$, у КГ цей показник дорівнював $11,50 \mathrm{~cm}$, або $5 \%(\mathrm{t}-2,23, \mathrm{p}<0,05)$. Потрійний стрибок із місця в КГ зріс на $3 \%(\mathrm{t}-2,04, \mathrm{p}<0,05)$, в ЕГ результат покращився на 46,38 см, або на $8 \%(\mathrm{t}-8,24, \mathrm{p}<0,05)$. У метанні ядра спиною вперед результат, показаний у КГ у кінці експерименту, зріс на 0,59 м, або на $5 \%$ (t-2,04, p $<0,05)$, тоді як ЕГ перевищила початковий результат на 1,13 м, або на $10 \%(\mathrm{t}-2,35, \mathrm{p}<0,05)$. У застрибуванні на тумбу 50 см за 30 сек у КГ результат за весь час покращився на $5,86$ раза, або на $15 \%$ (t-1,86, p>0,05), в ЕГ - на 18 разів, що становило $45 \%$ (t-3,11, $\mathrm{p}<0,05)$.

Підвищення максимальної сили, за даними кистьової динамометрії, у КГ - $18 \%$ правою рукою (t$2,43, \mathrm{p}<0,05)$ та $23 \%$ - лівою (t-3,14, $<<0,05)$, в ЕГ - $23 \%$ правою рукою $(\mathrm{t}-2,76, \mathrm{p}<0,05)$ і $32 \%$ - лівою $(\mathrm{t}-3,21, \mathrm{p}<0,05)$. У жимі штанги лежачи покращення в КГ становило 3,34 кг, або $5 \%(\mathrm{t}-2,77, \mathrm{p}<0,05)$, в ЕГ приріст дорівнював 7,6 кг, або $21 \%(\mathrm{t}-3,00, \mathrm{p}<0,05)$. У присіданні зі штангою на плечах покращення результату в КГ дало нам $9 \%$ приросту $(\mathrm{t}-2,23, \mathrm{p}<0,05)$, в експериментальній групі результати зросли на15\% (t-2,47, p <0,05). 
Силова підготовленість метальників КГ та ЕГ до й після експерименту

Таблиия 1

\begin{tabular}{|c|c|c|c|c|c|c|c|c|c|}
\hline \multirow{2}{*}{\multicolumn{3}{|c|}{ Тест }} & & \multirow{2}{*}{$\begin{array}{l}\text { Вхідні } \\
\text { дані }\end{array}$} & \multirow{2}{*}{$\begin{array}{c}\text { Кінцеві } \\
\text { дані }\end{array}$} & \multicolumn{2}{|c|}{ Приріст } & \multicolumn{2}{|c|}{ Достовірність } \\
\hline & & & & & & Од & $\%$ & $\mathbf{t}$ & $\mathbf{p}$ \\
\hline \multirow{8}{*}{\multicolumn{2}{|c|}{ 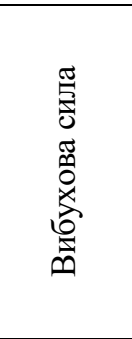 }} & \multirow{2}{*}{$\begin{array}{c}\text { Стрибок у довжину } \\
\text { з місця, } c м\end{array}$} & КГ & $212,50 \pm 12,47$ & $224,00 \pm 3,58$ & 11,50 & 5 & 2,23 & $\mathrm{p}<0,05$ \\
\hline & & & $\mathrm{e}$ & $211,64 \pm 11,82$ & $232,67 \pm 12,88$ & 21,03 & 11 & 3,24 & $\mathrm{p}<0,05$ \\
\hline & & \multirow{2}{*}{$\begin{array}{l}\text { Потрійний стрибок } \\
\text { iз місця, } c \text { м }\end{array}$} & Кг & $613,31 \pm 1,75$ & $629,32 \pm 1,62$ & 16,01 & 3 & 1,89 & $\mathrm{p}>0,05$ \\
\hline & & & ег & $612,24 \pm 5,28$ & $658,62 \pm 6,34$ & 46,38 & 8 & 8,24 & $\mathrm{p}<0,05$ \\
\hline & & \multirow{2}{*}{$\begin{array}{c}\text { Кидок ядра } 4 \text { кг через } \\
\text { голову назад, } \mu \\
\end{array}$} & КГ & $13,52 \pm 0,29$ & $14,11 \pm 0,12$ & 0,59 & 5 & 2,04 & $\mathrm{p}<0,05$ \\
\hline & & & $\mathrm{e}$ & $13,51 \pm 0,41$ & $14,64 \pm 0,62$ & 1,13 & 10 & 2,35 & $\mathrm{p}<0,05$ \\
\hline & & \multirow{2}{*}{$\begin{array}{c}\text { Стрибки на тумбу } \\
50 \text { см за } 30 \text { сек. }\end{array}$} & КГ & $39,51 \pm 1,36$ & $44,37 \pm 1,75$ & 4,86 & 12 & 1,86 & $\mathrm{p}>0,05$ \\
\hline & & & ег & $39,64 \pm 1,82$ & $57,64 \pm 2,31$ & 18,00 & 45 & 3,11 & $\mathrm{p}<0,05$ \\
\hline \multirow{8}{*}{\multicolumn{2}{|c|}{ 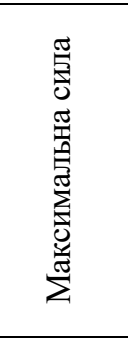 }} & \multirow{2}{*}{$\begin{array}{l}\text { Динамометрія } \\
\text { правої кисті, кг }\end{array}$} & КГ & $32,77 \pm 1,53$ & $38,76 \pm 1,49$ & 5,99 & 18 & 2,43 & $\mathrm{p}<0,05$ \\
\hline & & & $\mathrm{e}$ & $32,42 \pm 1,96$ & $39,70 \pm 1,76$ & 7,28 & 23 & 2,76 & $\mathrm{p}<0,05$ \\
\hline & & \multirow{2}{*}{$\begin{array}{l}\text { Динамометрія } \\
\text { лівої кисті, кट }\end{array}$} & КГ & $31,02 \pm 1,62$ & $38,12 \pm 1,73$ & 7,10 & 23 & 3,14 & $\mathrm{p}<0,05$ \\
\hline & & & $\mathrm{e} \Gamma$ & $30,17 \pm 2,01$ & $39,87 \pm 1,82$ & 9,7 & 32 & 3,21 & $\mathrm{p}<0,05$ \\
\hline & & \multirow{2}{*}{$\begin{array}{c}\text { Жим штанги } \\
\text { лежачи, кг }\end{array}$} & КГ & $65,01 \pm 2,32$ & $68,35 \pm 1,68$ & 3,34 & 5 & 2,77 & $\mathrm{p}<0,05$ \\
\hline & & & $\mathrm{e} \Gamma$ & $64,07 \pm 2,02$ & $71,67 \pm 1,53$ & 7,6 & 12 & 3,00 & $\mathrm{p}<0,05$ \\
\hline & & \multirow{2}{*}{$\begin{array}{c}\text { Присідання } \\
\text { зі штангою, кг }\end{array}$} & КГ & $68,73 \pm 1,96$ & $74,64 \pm 2,11$ & 5,91 & 9 & 2,23 & $\mathrm{p}<0,05$ \\
\hline & & & $\mathrm{e} \Gamma$ & $68,12 \pm 2,16$ & $78,24 \pm 2,48$ & 10,12 & 15 & 2,47 & $\mathrm{p}<0,05$ \\
\hline \multirow{8}{*}{ 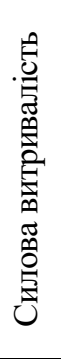 } & \multirow{4}{*}{ 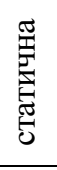 } & \multirow{2}{*}{$\begin{array}{c}\text { Вис на } \\
\text { зігнутих руках, } c\end{array}$} & КГ & $31,01 \pm 1,33$ & $34,39 \pm 1,36$ & 3,38 & 11 & 1,46 & $\mathrm{p}>0,05$ \\
\hline & & & $\mathrm{e} \Gamma$ & $31,28 \pm 3,46$ & $37,70 \pm 3,83$ & 6,42 & 17 & 2,01 & $\mathrm{p}<0,05$ \\
\hline & & \multirow{2}{*}{$\begin{array}{c}\text { Утримання ніг } \\
\text { у положенні лежачи, } c\end{array}$} & КГ & $31,03 \pm 2,14$ & $34,24 \pm 1,27$ & 2,21 & 10 & 1,48 & $\mathrm{p}>0,05$ \\
\hline & & & $\mathrm{e} \Gamma$ & $31,16 \pm 1,94$ & $38,93 \pm 1,19$ & 7,77 & 25 & 2,36 & $\mathrm{p}<0,05$ \\
\hline & \multirow{4}{*}{ 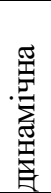 } & \multirow{2}{*}{$\begin{array}{c}\text { Підйом у сід } \\
\text { за } 30 \text { с (к-ть разів) }\end{array}$} & КГ & $22,02 \pm 1,16$ & $23,81 \pm 1,23$ & 1,79 & 10 & 0,98 & $\mathrm{p}>0,05$ \\
\hline & & & $\mathrm{e}$ & $21,65 \pm 1,06$ & $29,98 \pm 1,12$ & 8,38 & 39 & 2,32 & $\mathrm{p}<0,05$ \\
\hline & & \multirow{2}{*}{$\begin{array}{c}\text { Присідання } \\
\text { за } 20 \text { с (к-ть разів) }\end{array}$} & Кг & $19,77 \pm 2,21$ & $22,31 \pm 1,96$ & 2,54 & 13 & 1,85 & $\mathrm{p}>0,05$ \\
\hline & & & ег & $19,22 \pm 2,28$ & $27,67 \pm 1,13$ & 8,45 & 44 & 2,49 & $\mathrm{p}<0,05$ \\
\hline
\end{tabular}

Щодо показників статичної силової витривалості у висі на зігнутих руках результату, показаного в КГ у кінці експерименту, приріст становив 3,38 сек, або 11 \% (t-1,46, p>0,05), ЕГ перевищила початковий результат на $17 \%$, або 6,42 сек $(\mathrm{t}-2,01, \mathrm{p}<0,05)$. В утриманні ніг у положенні лежачи результат у КГ зріс на $10 \%(\mathrm{t}-1,48, \mathrm{p}>0,05)$, у КГ - на $25 \%(\mathrm{t}-2,36, \mathrm{p}<0,05)$.

Стосовно показників динамічної силової витривалості в підйомі в сід за 30 сек у КГ він покращився на 1,79 раза, або на $8 \%(\mathrm{t}-0,98, \mathrm{p}>0,05)$, в $\mathrm{EГ}$ - на $39 \%(\mathrm{t}-2,32, \mathrm{p}<0,05)$. У присіданні з вагою власного тіла за 20 сек результат в ЕГ зріс на $44 \%(\mathrm{t}-2,49, \mathrm{p}<0,05)$, у КГ - на $13 \%$ (t-1,85, p>0,05).

До того ж, як видно 3 табл. 2, якщо на початку нашого експерименту експериментальна група поступалася в спортивній майстерності, маючи шість результатів рівня III розряду й два - II-го, порівняно 3 5-ма результатами III розряду контрольної групи та 3-ма II-го, то в кінці нашого експерименту ми спостерігаємо динаміку підвищення спортивної майстерності в ЕГ (7-II розряд, 1-I-й), порівняно з КГ (6II розряд, 2-III-й).

Отже, як видно 3 результатів дослідження, у спортсменів експериментальної групи значно підвищилися не лише силові якості а й спортивний результат, порівняно з контрольною групою. Це свідчить про те, що різниця результатів викликана не випадковими фактами, а в результаті запровадження в тренувальний процес легкоатлетів-метальників груп підвищення спортивної майстерності кросфітпрограми та підтверджує правильність обраного напряму дослідження.

Таблиия 2

Спортивна майстерність КГ та ЕГ за весь час експерименту

\begin{tabular}{|c|c|c|c|c|}
\hline \multirow{2}{*}{ Спортивний розряд } & \multicolumn{2}{|c|}{ Експериментальна група } & \multicolumn{2}{c|}{ Контрольна група } \\
\cline { 2 - 5 } & початкові дані & кінцеві дані & початкові дані & кінцеві дані \\
\hline I & - & 1 & - & - \\
\hline II & 2 & 7 & 3 & 6 \\
\hline III & 6 & - & 5 & 2 \\
\hline
\end{tabular}


Висновки та перспективи подалыших досліджень. За результатами проведеного дослідження можна зробити висновок, що застосування тренувальної програми 3 підвищення силових якостей за допомогою засобів кросфіт дає позитивний ефект, який достовірно вищий, ніж за реалізації стандартної програми тренування легкоатлетів-метальників, що чітко підтверджено покращенням силових якостей $\mathrm{i}$ спортивних досягнень легкоатлетів-метальників експериментальної групи, що й дає змогу рекомендувати розроблену програму для використання в навчально-тренувальному процесі груп підвищення спортивної майстерності в закладах вищої освіти, ДЮСШ, ДЮСШОР і в спеціалізованих навчальних закладах спортивного профілю.

\section{Джерела та література}

1. Богачев Е. В., Карягин И. А. Кроссфит. Руководство по тренировкам. Москва: [б. и.], 2013. 142 с.

2. Базилевич Н. О., Тонконог О. С. (2017). Вплив занять кросфітом на формування мотивації студентів до регулярних занять фізичною культурою і спортом. Молодий вчений, 2017. № 2 (42), С. 113-117.

3. Волков В. В., Еремин С. А., Селуянов В. Н. Технология кроссфит: основы прикладности и условия уменьшения экстремальности высокоинтенсивной спортивной тренировки. Экстремальная деятельность человека: науч.-метод. журн. 2014. № 1 (30). С. 33-36.

4. Галимова А. Г., Кудрявцев М. Д., Глубокий В. А., Галимов Г. Я. Теоретическое обоснование методики высокоинтенсивного многофункционального тренинга Кроссфит. Вестник БГУ. Педагогика. Филология. Философия. Улан-Удэ, 2017. Вып. 4. Педагогика. С. 110-115.

5. Глубокий В. А. Кроссфит - новое направление силового фитнеса. Современные процессы развития физической культуры, спорта и туризма, состояние и перспективы формирования здорового образа жизни: материалы XV Традиционного междунар. симпозиума. Красноярск: СибГАУ, 2011. C. $142-145$.

6. Глассман Г. Статьи и журналы кроссфит. Теоретическая основа программ кроссфита. 2006. 5 с.

7. Зиамбетов В. Ю., Астраханкина Ю. С. Кроссфит как способ повышения эффективности физической подготовки студентов вуза. Молодой ученый. 2016. № 7. С. 1061-1063. URL: https://moluch.ru/ archive/111/27862/

8. Журнал о кроссфите и тяжёлой атлетике. URL: http://wodloft.ru

9. Кокорев Д. А., Выприков Д. В., Везеницин О. В. Методика использования функционального многоборья (кроссфита) в процессе физического воспитания студентов. Теория и практика физ. культуры, 2016, № 9. C. 16-18.

10. Юшкевич Т. П., Романов И. В. Применение элементов кроссфита в тренировочном процессе десятиборцев 15-16 лет. Мир спорта. 2017. o 1(66). С. 17-23.

11. Черкашин Р. Є, Валькевич О. В. Розвиток швидкісно-силових якостей легкоатлетів у групах підвищення спортивної майстерності: навч.-метод. рек. СНУ ім. Лесы Українки. Луцьк, 2018. 50 с.

\section{References}

1. Bogachev, E. V., Karyagin, I. A. (2013). Krossfit. Rukovodstvo po trenirovkam [CrossFit. Training Guide]. Moskva, 142.

2. Bazylevych, N. O., Tonkonoh, O. S. (2017). Vplyv zaniat krosfitom na formuvannia motyvatsii studentiv do rehuliarnykh zaniat fizychnoiu kulturoiu i sportom [The influence of CrossFit on the formation of students' motivation for regular physical education and sports]. Molodyi vchenyi, 2 (42), 113-117.

3. Volkov, V. V., Eremin, S. A., Seluyanov, V. N. (2014). Tehnologiya krossfit: osnovyi prikladnosti i usloviya umensheniya ekstremalnosti vyisokointensivnoy sportivnoy trenirovki [CrossFit technology: applied fundamentals and conditions for reducing the extremes of high-intensity sports training]. Ekstremalnaya deyatelnost cheloveka: nauchno-metodicheskiy zhurnal, 1 (30), 33-36.

4. Galimova, A. G., Kudryavtsev, M. D., Glubokiy, V. A., Galimov, G. Ya. (2017). Teoreticheskoe obosnovanie metodiki vysokointensivnogo mnogofunktsionalnogo treninga Krossfit [Theoretical affirmation of the methodology of high-intensity multifunctional training of CrossFit]. Vestnik BGU. Pedagogika. Filologiya. Filosofiya. Ulan-Ude, $4,110-115$.

5. Glubokiy, V. A. (2011). Krossfit - novoe napravlenie silovogo fitnesa [CrossAit - a new direction of power fitness]. Sovremennyie protsessyi razvitiya fizicheskoy kulturyi, sporta i turizma, sostoyanie i perspektivyi formirovaniya zdorovogo obraza zhizni, Materialyi XV Traditsionnogo mezhdunar. simpoziuma. Krasnoyarsk: SibGAU, 142-145.

6. Glassman, G. (2006). Stati i zhurnalyi krossfit. Teoreticheskaya osnova programm krossfita [Articles and CrossFit Journals. Theoretical basis of CrossFit programs], 5.

7. Ziambetov, V. Yu., Astrahankina, Yu. S. (2016). Krossfit kak sposob povysheniya effektivnosti fizicheskoy podgotovki studentov vuza [CrossFit as a way of improving the efficiency of physical training of university students]. Molodoy uchenyiy, 7, 1061-1063. Refrieved from: https://moluch.ru/archive/111/27862/ 
8. Zhurnal o krossfite i tyazholoy atletike [Journal of CrossFit and Weightlifting.]. Refrieved from: http://wodloft.ru

9. Kokorev, D. A., Vyiprikov, D. V., Vezenitsin, O. V. (2016). Metodika ispolzovaniya funktsionalnogo mnogoborya (krossfita) v protsesse fizicheskogo vospitaniya studentov. Teoriya i praktika fizicheskoy kultury [Methods of using functional multisport race (CrossFit) in the process of students physical education], 9, 16-18.

10. Yushkevich, T. P., Romanov I. V. (2017). Primenenie elementov krossfita v trenirovochnom protsesse desyatibortsev 15-16 let [The use of CrossFit elements in the training process of decathlon competitors 15-16 years of age]. Mir Sporta, 1(66), 17-23.

11. Cherkashyn, R. Ye, Valkevych, O. V. (2018). Rozvytok shvydkisno-sylovykh yakostei lehkoatletiv u hrupakh pidvyshchennia sportyvnoi maisternosti [The development of strongworking qualities among athletes in sports groups of the master's trainings]. Navchalno-metodychni rekomendatsi. SNU im. Lesi Ukrainky, Lutsk, 50.

Стаття надійшла до редакції 24.04.2019 p. 